\title{
Learner Autonomy and the Use of Language Learning Strategies in a Taiwanese Junior High School
}

\author{
Hsiang-I Chen (Corresponding author) \\ Department of Applied English, Ming Chuan University \\ No.5 De Ming Rd., Gui Shan District, Taoyuan City 333, Taiwan \\ Tel: 886-3-350-7001 ext. 3211 E-mail: achen2000@hotmail.com \\ Hung-Hsi Pan \\ Department of Applied English, Ming Chuan University \\ No.5 De Ming Rd., Gui Shan District, Taoyuan City 333, Taiwan \\ Tel: 886-3-350-7001 ext. $3211 \quad$ E-mail: ccpan99@gmail.com
}

Received: Jan. 19, 2014 Accepted: Jan.26, 2014 Published: February 1, 2015

doi:10.5296/jse.v5i1.6972 URL: http://dx.doi.org/10.5296/jse.v5i1.6972

\begin{abstract}
English learning autonomy and language learning strategies are key dimensions in learners' English performance. However, empirical research findings concerning the relationships of learner autonomy and learning strategies are still translucent in Taiwan. There are 130 ninth graders from a junior high school in central Taiwan participating to determine: (1) the language learning strategies they preferred; (2) their level of English learning autonomy; and (3) the relationship between English learning autonomy and language learning strategies. The results of the quantitative research method show that participants in this study had a medium level of English learning autonomy and an infrequent use of language learning strategies. Junior high school learners tend to use memory strategies most frequently and affective strategies least frequently. Students seldom participated in English related activities after school. In addition, a correlation was found between learners' learning autonomy levels and the use of language learning strategies. Practical suggestions are offered for teachers in order to help junior high students become autonomous learners in the field of language learning.
\end{abstract}

Keywords: learner autonomy, Language learning strategies, Junior high school, English learning, EFL context 


\section{Introduction}

Research on foreign and second language acquisition during 1970s and 1980s generally centered more on pedagogy than on learning processes. Since 1990s, the research focus has shifted to take into account the interaction between teacher and learner from the perspective of the learner (Brown, 2000). Collectively, researchers have identified a number of cognitive, affective, and socio cultural factors contributing to learners' English proficiency. Empirical research investigations in Taiwan are also abundant. One common is that language learning strategies have often emerged as a significant variable.

English learning is a lifelong journey, not one that begins and ends in a language classroom. During this process, learners should be taught and guided to become autonomous and take the responsibility of their learning so as to improve their language skills. When they leave the school, learners are able to direct their own learning and choose learning activities. It is observed that successful learners are autonomous and capable to use learning strategies properly (Oxford, 1996). In brief, efficient and effective language learning experience requires autonomy and strategies.

Recent literature in relation to learner autonomy in Taiwan mostly took university students or adult learners as research subjects (e.g. Chang, 2012; Cheng, 2007; Lee, Good, \& Chen, 2007). Research focus on the use of learning strategies and learner autonomy in language learning is relatively limited. Therefore, this study aims to explore the degree of English learning autonomy among Taiwanese junior high school students and their use of language learning strategies. It is hoped that the findings of this study would provide solid empirical evidence for English teachers at junior high schools and shed light on the training of learning strategy use and autonomy in Taiwan

Based on the purposes of the present study, the research questions are addressed as follows:

\section{Research Questions}

1. What language learning strategies are used by junior high school students?

2. To what extent the language learning autonomy are held by junior high school participants?

3. To what extent does learner autonomy of junior high school learners correlate with their use of language learning strategies?

\section{Literature Review}

\subsection{Learner autonomy}

The most widely evoked definition conceives of learner autonomy as the "ability to take charge of one's own learning" (Holec, 1981, p. 3). Learners take their first step towards autonomy when they realize that they need to be responsible for their own learning (Little, 1991). Learners have to determine their own learning goal, contents and progression and select methods and proper techniques to be used during the learning journey (Cotterall, 2000). According to Smith (2007), learner autonomy is activated when "learners have the power and 
right to learn for themselves" (p. 2). Both definitions focus autonomous learners as human beings free from external constraints. Nunan (1995) identified various elements of a successful autonomous learner including: diversity of skills, passion, enjoyment for a particular field, a focused and active approach to learning, and a willingness to continue even if there is a high probability of failure and public disapproval.

Second language teachers and researchers have been interested in the factors accounting for success in learning a second or foreign language (e.g. Deng 2004; Holec, 1981; Little, 1991). One of the factors is autonomous learning. Learner autonomy through a focus on learner reflection and taking responsibility for one's own learning process has become acentral concern in the recent history of language teaching (e.g. Benson,2007; Lamb \& Reinder, 2008; Little,2009). According to Holec(1981), learning autonomy plays a key role in raising learning outcome. A similar correlation between learning autonomy and language learning outcomes was found in Taiwanese EFL contexts by Yang (1998) and Lo (2010). The ultimate goal for students is taking control of their own learning and becoming autonomous learners both in and out of the classroom.

Autonomous learning is an empirical approach to foreign language learning and foreign language teaching. Researchers from different countries have noted that English learning autonomy is positively related to English performance. In Vietnam, Le (2013) reported the effective training program improved learners' English language proficiency and learner autonomy. Li (2004) declared that learner autonomy promotion is feasible in tertiary education and has significant proficiency gains. Borg and Ai-Busaidi (2012) declared the importance of promoting learner autonomy in the process of foreign language learning. Parisa (2013) indicated that the relationship between English proficiency and Iranian high school learner's autonomy is relatively high. Similarly, Indonesian college learners' autonomy and English proficiency was reported a significant correlation (Myartawan, Latief \& Suharmanto, 2013). In China, Dafei(2007) also found that the Chinese college students' English proficiency was related to their learner autonomy. In a nutshell, development of learner autonomy is very important for language learners because language learning is a lifelong task.

\subsection{Studies on language learning strategies}

Language learning strategies (LLS) are a series of tools that learners can use to help them learn a new language more effectively. These tools consist of specific actions, behavior, steps or techniques that students often intentionally employ to improve their learning progress in second language acquiring (Oxford, 1990). Oxford (1990) classified learning strategies into six groups: memory strategies, cognitive strategies, compensation strategies, metacognitive strategies, affective strategies and social strategies. These six types of strategies were further divided into direct strategies (i.e. memory, cognitive, compensation, and indirect strategies (i.e. metacognitive, affective, social) (Oxford, 1990). Direct strategies involve those behaviors and activities related to language learning directly. Indirect strategies are regarded that they support and manage language learning without directly involving the target language. 
These six categories of language learning strategies were then developed into a measure of learners' use of strategies 'Strategy Inventory for Language Learning' (SILL)and have been used extensively with proven validity and reliability (Oxford \& Burry-Stock, 1995; Oxford \& Nyikos, 1989), although there are some aspects of SILL have been criticized (Nguyen \& Godwyll, 2010; Woodrow, 2005). However, much research uses SILL to study the use of language learning strategies, as shown in the findings listed below.

Language learning strategies have been studied and proven to play an empirical tool in successful language learning worldwide, such as the studies carried out by using American samples (Anderson, 2002), Japanese college students (Watanabe, 1990), and Singaporean samples (Wharton, 2000). In Taiwan, a body of research regarding learning strategies employed Oxford's 6-factor taxonomy. For instance, Yang (1993) reported high-achieving high school learners use language learning strategies more frequently than low-achieving high school students. Yang (2007) and Lai (2009) had a similar finding in college contexts. Hsiao and Oxford (2002) confirmed the strategy theories in Taiwan.

Second language teachers and researchers have been interested in the factors accounting for success in learning a second or foreign language (Deng, 2004; Holec, 1981; Little, 1997). One of the factors is autonomous learning. Yet, strategy training, especially in metacognitive strategies, was suggested as a key for promoting learner autonomy (Weden 1991). There have been many research projects and papers that deal with the issue of autonomy in foreign language learning. More and more language teachers are focusing on developing students' ability in learning language independently. It is important that strategy-based instruction and learner training are not limited to teaching an approved set of strategies; instead, learners should be trained to use strategies flexibly, appropriately and independently, which will help them become autonomous learners.

\section{Methodology}

\subsection{Participants}

The present study was conducted in a junior high school in central Taiwan. The researchers used convenience sampling to select the participants. The questionnaires about language learning strategies and language learning autonomy were administered to 130ninth graders; 69 of them were female and 61 of them were male students. One hundred and thirty valid questionnaires were returned, for a response rate of $100 \%$.

\subsection{Instruments}

The questionnaire included three parts: (1) demographic information such as gender, age, whether they attended additional English lessons after school, and number of years of learning English in cram schools; (2) Autonomy Inventory about language learning (Üstunluoglu. 2009); and(3) Strategy Inventory for Language Learning (Oxford, 1990).Learner Autonomy Inventory contains three subscales: students' responsibility, students' abilities, and students' activities. The responsibility section (items 1-10) was arranged using the following descriptors: 'student's responsibility,' 'teacher's responsibility,' and 'both,' while the ability section (items 11-18) was arranged using a 5- point Likert scale 
(very poor, poor, okay, good, very good). The rest 19 questions in relation to autonomous activities were also arranged using a 5- point Likert scale(never, seldom, sometimes, often, and always). There are 37 autonomous items in total.

Oxford's (1990) Strategy Inventory for Language Learning (SILL, EFL/ESL 7.0 version, revised by Chen, 2008) was employed to measure the use of learning strategies in this study. The internal consistency was found good in Chen's study (Cronbach's alpha .94). There were 27 items that include direct strategies and indirect strategies using a 4 - point Likert scale (strongly agree, agree, disagree, and strongly disagree).

The ages of the participants of this study is different from those in previous studies, so there is a need to retest the reliability of the two scales in order to determine if it is necessary to modify the instruments for junior high school learners in the main study. Thus, the pilot study was carried out at the same school. The Alpha coefficient for the Learner Autonomy Inventory is 0.938 , and for the Strategy Inventory for Language Learning is 0.891 . The reliability result suggests that the items of both measurements have relatively high internal consistency.

\subsection{Data Collection and Analysis}

Data collection and analysis in this study were based on the quantitative research approaches. The data was analyzed by using the SPSS (Statistical Packages for the Social Sciences, version 18.0). Statistical analysis methods employed in the current study consisted of descriptive statistics and inferential statistics. Specifically, various t-tests were used to explore the differences in the subjects' language learning strategies and autonomy between genders and among students with different amounts of study time in cram school. Students' response for each subscale of learner autonomy and learning strategies was analyzed as well.

\section{Results}

\subsection{Use of language learning strategies}

One-sample $t$-tests were performed to examine whether each subscale's respective mean score was significantly different from the midpoint score (i.e., the generally accepted mean $=2.5$ in a 4-point Likert scale). As Table 1 displays, the subjects used all (Items 1-27) language learning strategies $(\mathrm{M}=2.63, \mathrm{SD}=.53)$ at a medium to high level of frequency, which is statistically significant at the $<.01$ level. Specifically, participants utilized memory strategies $(\mathrm{M}=2.89, \mathrm{SD}=.63)$ more frequently than other strategies. Cognitive strategies $(\mathrm{M}=2.81$, $\mathrm{SD}=.68)$, and compensation strategies $(\mathrm{M}=2.83, \mathrm{SD}=.62)$ were employed at a medium level of frequency. However, learners used social strategies $(\mathrm{M}=2.49$, $\mathrm{SD}=.64)$ metacognitive strategies $(\mathrm{M}=2.46, \mathrm{SD}=.67)$, and affective strategies $(\mathrm{M}=2.29, \mathrm{SD}=.64)$, at a medium to low level of frequency. Statistical significance was only found in the use of affective strategies $(t(129)=-3.65, p<.001)$. It means that the use of affective strategies was relatively occasional by middle school students in Taiwan. 


\section{Mll Macrothink}

Table 1. The Use of Learning Strategy by Junior High Students (test value=2)

\begin{tabular}{lllll}
\hline Item description & $\begin{array}{l}\text { Item of the } \\
\text { questionnaire }\end{array}$ & $\begin{array}{l}\text { Number of the } \\
\text { items }\end{array}$ & Mean & SD \\
\hline Overall & $1-27$ & 27 & $2.63^{* *}$ & 0.53 \\
\hline Memory strategy & 1.2 .3 .4 & 4 & $2.89^{* *}$ & 0.62 \\
Compensation strategy & 9.10 .11 .12 .13 & 5 & $2.83^{* *}$ & 0.61 \\
Cognitive strategy & 5.6 .7 .8$. & 4 & $2.81^{* *}$ & 0.67 \\
Social strategy & 23.24 .25 .26 .27 & 5 & 2.49 & 0.64 \\
Metacognitive strategy & 14.15 .16 .17 .18 & 5 & 2.46 & 0.66 \\
Affective strategy & 19.20 .21 .22 & 4 & $2.29^{* *}$ & 0.64 \\
\hline
\end{tabular}

Note: ${ }^{*} p<.01 ; 4-P o i n t$ Scale; SD=Standard Deviation

\subsection{Degree of junior high students'learning autonomy}

Junior high school students' autonomy levels in learning English were measured in terms of three dimensions: responsibility, ability, and activity. The percentage of the attribution of responsibility for English learning is shown in Table 2. Results show that most participants tend to think they have more responsibility for their English learning compared to their teacher's responsibility. In contrast, the results from (item 6, 7, and 8) yielded that junior high learners regarded some English learning activities as the teacher's responsibilities. It's not surprising to learn that students considered those tasks as teacher's responsibilities since it's very common that the subject teacher decides the learning activities in a teacher-centered environment. 
Table 2. Students' Attitudes toward English Learning Responsibility

\begin{tabular}{|c|c|c|c|c|c|c|}
\hline \multirow{2}{*}{$\begin{array}{l}\text { Item } \\
\text { number }\end{array}$} & \multirow{2}{*}{ Item's statement } & \multirow{2}{*}{$\mathrm{M}$} & \multirow{2}{*}{ SD } & \multicolumn{3}{|c|}{ Responsibility (\%) } \\
\hline & & & & Mine & My teacher's & Both \\
\hline 1 & $\begin{array}{l}\text { To ensure you make progress } \\
\text { during English lessons }\end{array}$ & 1.58 & .90 & $70.00 \%$ & $2.30 \%$ & $27.70 \%$ \\
\hline 2 & $\begin{array}{l}\text { To ensure you learn English } \\
\text { outside class }\end{array}$ & 1.12 & .43 & $91.60 \%$ & $4.60 \%$ & $3.80 \%$ \\
\hline 3 & $\begin{array}{l}\text { To know which way to stimulate } \\
\text { your interest in learning English }\end{array}$ & 1.98 & .92 & $43.10 \%$ & $15.40 \%$ & $41.50 \%$ \\
\hline 4 & $\begin{array}{l}\text { To identify your weaknesses in } \\
\text { English }\end{array}$ & 1.48 & .83 & $73.80 \%$ & $4.60 \%$ & $21.60 \%$ \\
\hline 5 & $\begin{array}{l}\text { To decide the objectives of } \\
\text { making progress in your English } \\
\text { course }\end{array}$ & 1.42 & .80 & $76.90 \%$ & $3.80 \%$ & $19.30 \%$ \\
\hline 6 & $\begin{array}{l}\text { To decide what you should learn } \\
\text { next semester in your English } \\
\text { lessons }\end{array}$ & 2.08 & .68 & $19.30 \%$ & $53.80 \%$ & $26.90 \%$ \\
\hline 7 & $\begin{array}{l}\text { To choose what activities to use } \\
\text { to learn English in your English } \\
\text { lessons }\end{array}$ & 1.96 & .60 & $20 \%$ & $63.80 \%$ & $16.20 \%$ \\
\hline 8 & $\begin{array}{l}\text { To decide how long to spend on } \\
\text { each activity }\end{array}$ & 1.82 & .66 & $32.40 \%$ & $53.80 \%$ & $13.80 \%$ \\
\hline 9 & $\begin{array}{l}\text { To choose what materials to use } \\
\text { to learn English in your English } \\
\text { lessons }\end{array}$ & 1.32 & .69 & $81.50 \%$ & $5.40 \%$ & $13.10 \%$ \\
\hline 10 & $\begin{array}{l}\text { To understand how much your } \\
\text { learned }\end{array}$ & 1.29 & .70 & $84.70 \%$ & $3.80 \%$ & $11.50 \%$ \\
\hline
\end{tabular}

Note: 1 = my responsibility; $2=$ teacher's responsibility; $3=$ both

One-sample $t$-testswere conducted on the scores of their perceived autonomous ability and 
activity of the autonomy scale to evaluate whether the averages cores were significantly different from the midpoint 3 . Table 3 shows that in the ability section, participants demonstrated high autonomous degrees of some specific ability items. For instance, they considered they have the ability to set their English learning goals (Item 12), know their weaknesses (Item 16), and identify their level (Item 17). In contrast, they thought they lack the ability to choose English learning activities (Item 11) and reading materials (Item 14). As to students' attitudes towards English learning activities, they well participated in those activities in relation to assignments (Item 19), rote memorization of vocabulary (Item 20), and the tasks assigned by teachers (Item 35). However, they don't attend a study group for English language (Item 28) and seldom discussed their learning difficulties with teachers (Item 21). More, they rarely engaged in informal English learning activities after school, such as reading English materials (Item 25) and talking to friends in English (Item 26). Generally speaking, junior high learners tend to avoid participating in English learning activities (See Table 4).

Table 3. Students' Attitudes towards Autonomous Ability (test value=3)

\begin{tabular}{lllll|lllll}
\hline item & $\mathrm{N}$ & mean & $\mathrm{SD}$ & Sig. & item & $\mathrm{N}$ & mean & SD & Sig. \\
\hline a11 & 130 & $2.65^{* *}$ & .99 & .000 & $\mathrm{a} 15$ & 130 & 3.06 & 4.69 & .881 \\
$\mathrm{a} 12$ & 130 & $3.45^{* *}$ & 1.08 & .000 & $\mathrm{a} 16$ & 130 & $3.27^{* *}$ & 1.01 & .003 \\
$\mathrm{a} 13$ & 130 & $2.72^{* *}$ & .99 & .002 & $\mathrm{a} 17$ & 130 & $3.25^{* *}$ & .95 & .003 \\
$\mathrm{a} 14$ & 130 & $2.27^{* *}$ & .93 & .000 & $\mathrm{a} 18$ & 130 & 3.05 & 1.05 & .616 \\
\hline
\end{tabular}

Note: 1 =very poor, 2=poor, 3=okay, 4=good, $5=$ very good; 
Table 4. Students' Attitudes towards Participating English Learning Activities (test value=3)

\begin{tabular}{|c|c|c|c|c|c|c|c|c|c|}
\hline item & $\mathrm{N}$ & mean & SD & Sig. & item & $\mathrm{N}$ & mean & SD & Sig. \\
\hline a19 & 130 & $4.10^{* *}$ & .96 & .000 & a29 & 130 & $2.73 * *$ & 1.17 & .010 \\
\hline $\mathrm{a} 20$ & 130 & $3.76^{* *}$ & 1.05 & .000 & a30 & 130 & $2.26^{* *}$ & .98 & .000 \\
\hline a21 & 130 & $2.31 * *$ & 1.04 & .000 & a31 & 130 & 3.18 & 1.17 & .087 \\
\hline $\mathrm{a} 22$ & 130 & $2.33 * *$ & .94 & .000 & a32 & 130 & 3.15 & 1.28 & .196 \\
\hline $\mathrm{a} 23$ & 130 & $2.12 * *$ & .95 & .000 & a33 & 130 & $3.52 * *$ & 1.25 & .000 \\
\hline a24 & 130 & 2.89 & 1.20 & .306 & a34 & 130 & 2.89 & 1.11 & .270 \\
\hline $\mathrm{a} 25$ & 130 & $1.75^{* *}$ & 1.05 & .000 & a35 & 130 & $3.69 * *$ & 1.09 & .000 \\
\hline a26 & 130 & $1.65^{* *}$ & .806 & .000 & a36 & 130 & $2.49 * *$ & 1.12 & .000 \\
\hline $\mathrm{a} 27$ & 130 & $1.78^{* *}$ & .76 & .000 & a37 & 130 & 3.02 & 1.19 & .883 \\
\hline a28 & 130 & $1.40^{* *}$ & .74 & .000 & & & & & \\
\hline
\end{tabular}

Note: 1 =never, 2 =seldom, $3=$ sometimes, 4=often, $5=$ always

\subsection{Relationship between learning strategies and learner autonomy}

Table 5explains that there are positive correlations between language learning autonomy and six categories of language learning strategies. The results indicate those who have higher level of autonomy in the ability and activity sections tend to apply language learning strategies more frequently. The highest significant correlation $(r=.74, p<.001)$ is between the activity section of autonomy and cognitive strategies, which indicates that learners who are more autonomous for English learning activities are very likely to use cognitive strategies often. 
Table 5. Pearson Correlation Analysis: Relationship between the six learning strategies and three level of English Learning Autonomy.

\begin{tabular}{lllllll}
\hline Learning strategy/ & $\begin{array}{l}\text { Memory } \\
\text { strategy }\end{array}$ & $\begin{array}{l}\text { Cognitive } \\
\text { strategy }\end{array}$ & $\begin{array}{l}\text { Compensation } \\
\text { strategy }\end{array}$ & $\begin{array}{l}\text { Metacognitive } \\
\text { strategy }\end{array}$ & $\begin{array}{l}\text { Affective } \\
\text { strategy }\end{array}$ & $\begin{array}{l}\text { Social } \\
\text { strategy }\end{array}$ \\
\hline Responsibility & 0.104 & $0.198^{*}$ & 0.071 & 0.061 & -0.036 & 0.055 \\
Ability & $0.356 * *$ & $0.527 * *$ & $0.457 * *$ & $0.524 * *$ & $0.311 * *$ & $0.517 * *$ \\
Activity & $0.523 * *$ & $0.736 * *$ & $0.596 * *$ & $0.665 * *$ & $0.502 * *$ & $0.611 * *$ \\
\hline
\end{tabular}

Note: ${ }^{* *} p<.01$

\section{Conclusion and Suggestions}

This study aimed to provide significant evidence on the relationships between learners' English learning autonomy and their learning strategy use. As shown in the current study, junior high learners were not frequent users of language learning strategies. Similar to some previous investigations, Taiwanese learners preferred to use memory strategy (e.g. Chiu, 2014; Oxford, 2003; Yang, 2007). In addition, the strategy that students used least was affective strategy. It is known that many junior high learners are worried that people may correct the mistakes they make in learning English, and they also get nervous easily. Moreover, they may not be willing to share their own learning experiences with others. As a result, the goal for the English teacher is to help junior high learners overcome the fear of getting mistakes corrected and to help them be more willing to share their opinions with peers while learning English. To help students tackle the problems, teachers can encourage or ask students who is good at English to help those who are not during the tedious learning process.

Another strategy category junior high learners used less frequently was the groups of metacognitive strategies. It also indicates that participants lack English learning motivation. English teachers may help learners develop their metacognitive strategies by setting learning goals, making learning plans, and monitoring and assessing their own learning process.

Generally speaking, participants in the present study had positive attitudes toward learning responsibility; however, they were not involved in English learning related activities frequently. One of the reasons might be that they were afraid to speak English. Gradually, they lost confidence and interest in participating in English learning activities and thus, they tend to avoid relevant learning activities. Those could be the reasons leading to such contradictory results.

In order to fully engage students in English classes and then raise their autonomy, English teachers can allow learners to choose appropriate learning activities they favor and to decide how long a task will be. Students could also be allowed to discuss learning goals and materials with the teacher. This method may consequently raise learners' English learning 
motivation and arouse their interests. In short, English teachers should consider how to give learners some direction and freedom to inspire their creativity, motivation, and autonomy. For instance, implementing carefully-structured tasks (e.g. portfolios, designing exam for themselves) which require students to learn English in their own ways can enhance students' motivation and facilitate learning as well.

Significant correlations were found among the junior high learners' use of learning strategies and their level of learning autonomy. The results revealed that learners who had higher levels of learning abilities and engaged more in learning activities would frequently use language learning strategies. As a result, English teachers may encourage learners to foster various English learning habits in order to have more opportunities to acquire English in diversity ways, such as reading English materials and watching English programs or films. Future studies could consider to examine the effectiveness of these suggesting approaches in an EFL classroom.

\section{References}

Anderson, N. J. (2002). The Role of Metacognition in Second Language Teaching and Learning. ERIC Digest.

Benson, P. (2007). Autonomy in language teaching and learning. Language Teaching, 40(01), 21-40. http://dx.doi.org/10.1017/S0261444806003958

Borg, S., \& Al-Busaidi, S. (2012). Learner autonomy: English language teachers' beliefs and practices. ELT Journal, 12(7), 1-45.

Brown, H. D. (2000). Principles of language learning and teaching. New York: Pearson Education.

Chamot, A. U. (1998). Teaching learning strategies to language students. (ERIC Document Reproduction Services No. ED 433 719).

Chang, K. C. C. (2012). Fostering learner autonomy through empowering students in EFL writing. English Teaching and Learning, 36(3), 39-85.

Cheng, H. W. (2007). An investigation of EFL university students' outside learning tasks and autonomous learning. Unpublished master's thesis, National Chung Cheng University, Chiayi, Taiwan.

Chiu, M. K. (2014). A Study on Language Learning Strategy Use: A Case Study of Elementary School Students in Taiwan. Unpublished Master's thesis, Dayeh University, Taiwan.

Cohen, A. D. (1998). Strategies in learning and using a second language. London and New York: Longman.

Cotterall, S. (2000). Promoting learner autonomy through the curriculum: Principles for designing language courses. ELT journal, 54(2), 109-117.http://dx.doi.org/10.1093/elt/54.2.109 


\section{Macrothink}

Journal of Studies in Education

ISSN 2162-6952

2015, Vol. 5, No. 1

Dafei, D. (2007). An Exploration of the Relationship Between Learner Autonomy and English Proficiency. Asian EFL Journal, 24, 1-23.

Deng, L.(2004). Cultivating foreign language learners' autonomous learning. Journal of Sichuan Foreign Language University2, 156-159.

Holec, H. (1981). Autonomy and Foreign Language Learning. Oxford: Pergamon.

Hsiao, T. Y., \& Oxford, R. L. (2002). Comparing theories of language learning strategies: A confirmatory factor analysis. The Modern Language Journal, 86(3), 368-383.http://dx.doi.org/10.1111/1540-4781.00155

Lai, Y. C. (2009). Language learning strategy use and English proficiency of university freshmen in Taiwan. TESOL quarterly, 43(2), 255-280.

Lamb, T., \&Reinders, H. (Eds.). (2008). Learner and Teacher Autonomy: Concepts, realities, and response (Vol. 1). John Benjamins Publishing.

Le, Q. X. (2013). Fostering learner autonomy in language learning in tertiary education: an intervention study of university students in Hochiminh City, Vietnam (Doctoral dissertation, University of Nottingham).

Lee, M. L., Chen, R. S., \& Good, R. L. (2007). Fostering learner autonomy through aMultimedia English Learning Center. Journal of Applied Foreign Languages, 6:1 17. Kaohsiung, Taiwan: National Kaohsiung First University of Science and Technology.

Li, H. (2004). Developing Learner Autonomy in Chinese Tertiary Education. Journal of Beijing Institute of Technology (Social Sciences Edition), S1.

Little, D. (1991). Learner autonomy: Definitions, issues and problems. Authentik Language Learning Resources Limited.

Little, D. (1997). Language awareness and the autonomous language learner. Language Awareness, 6(2-3), 93-104.http://dx.doi.org/10.1080/09658416.1997.9959920

Little, D. (2009). Language learner autonomy and the European language portfolio: Two L2 English examples. Language

222-233.http://dx.doi.org/10.1017/s0261444808005636

teaching, 42(02),

Lo, Y. F. (2010). Implementing reflective portfolios for promoting autonomous learning among EFL college students in Taiwan. Language Teaching Research, 14(1), 77-95.http://dx.doi.org/10.1177/1362168809346509

Myartawan, W.; Latief, M.A. \&Suharmanto. (2013). The Correlation Between Learner Autonomy and English Proficiency of Indonesian EFL College Learners. TEFLIN Journal (24) $1,63-81$.

Nguyen, N., \& Godwyll, F. (2010). Factors Influencing Language-Learning Strategy Use of English Learners in an ESL Context. Mid-Western Educational Researcher, 23(4), 7-13.

Nunan, D. (1995). Closing the gap between learning and instruction, TESOL Quarterly, 29(1), 
133-158.http://dx.doi.org/10.2307/3587808

Oxford, R. L. (1990). Language learning strategies: What every teacher should know. Boston: Heinle \& Heinle Publishers.

Oxford, R. L. (Ed.). (1996). Language learning strategies around the world: Cross-cultural perspectives (No. 13). Natl Foreign Lg Resource Ctr.

Oxford, R. L., \& Burry-Stock, J. A. (1995). Assessing the use of language learning strategies worldwide with the ESL/EFL version of the strategy inventory for language learning (SILL). System, 23(1), 1-23.http://dx.doi.org/10.1016/0346-251x(94)00047-a

Oxford, R., \&Nyikos, M. (1989). Variables affecting choice of language learning strategies by university students. The Modern Language Journal, 73, 291-300.http://dx.doi.org/10.1111/j.1540-4781.1989.tb06367.x

Parisa, M. (2013).Realization of Autonomy and English Language Proficiency among Iranian High School Students. Theory and Practice in Language Studies, (3) 7, 1187-1193.http://dx.doi.org/10.4304/tpls.3.7.1187-1193

Smith, R. (2007). Learner autonomy. ELT journal, 62(4), 395-397.http://dx.doi.org/10.1093/elt/ccn038

Üstünlüoğlu, E. (2009). Autonomy in Language Learning: Do Students Take Responsibility for Their Learning? Journal of Theory and practice in Education, 5(2), 148-169.

Watanabe, Y. (1990). External variables affecting language learning strategies of Japanese EFL learners: Effects of entrance examination, years spent at college/university, and staying overseas. Unpublished master's thesis, Lancaster University, Lancaster, England

Wenden, A. L. (1991). Learner strategies for learner autonomy: Planning and implementing learner training for language learners. Prentice-Hall International. Hertfordshire, UK.

Wharton, G. (2000). Language learning strategy use of bilingual foreign language learners in Singapore. Language learning, 50(2), 203-243.http://dx.doi.org/10.1111/0023-8333.00117

Woodrow, L. (2005). The challenge of measuring language learning strategies. Foreign Language Annals, 38(1), 90-100.http://dx.doi.org/10.1111/j.1944-9720.2005.tb02456.x

Yang, M. N. (2007). Language learning strategies for junior college students in Taiwan: Investigating ethnicity and proficiency. Asian EFL journal, 9(2), 35-57.

Yang, N. D. (1998). Exploring a new role for teachers: Promoting learner autonomy. System, 26(1), 127-135. http://dx.doi.org/10.1016/s0346-251x(97)00069-9

Yang, P. L. (1993). Learning Strategies and Techniques Among High-achieving Students of English as a Foreign Language in ROC's High Schools. Unpublished Master's thesis, National Kaohsiung Normal University, Taiwan. 